\title{
Cowbane, Oxypolis occidentalis, A New Native Vascular Plant Species for the Queen Charlotte Islands, British Columbia
}

\author{
Michael Cheney ${ }^{1}$ and Kendrick L. MARR ${ }^{2}$ \\ ${ }^{1}$ Box 556, Masset, British Columbia V0T 1M0 Canada; deceased November 2007 \\ ${ }^{2}$ Royal British Columbia Museum, 675 Belleville Street, Victoria, British Columbia V8W 9W2 Canada
}

Cheney, Michael, and Kendrick L. Marr. 2007. Cowbane, Oxypolis occidentalis, a new native plant species for the Queen Charlotte Islands, British Columbia. Canadian Field-Naturalist 121(4): 421-422.

We report the recent discovery of Oxypolis occidentalis, a species that is new to both British Columbia and Canada, disjunct on the Queen Charlotte Islands.

Key Words: Native vascular plants, new records, Oxypolis occidentalis, Cowbane, Apiceae, Queen Charlotte Islands, British Columbia, Canada.

The Queen Charlotte Islands, a group of islands lying off the north coast of British Columbia, continue to yield new and interesting floristic finds. In the summer of 2001, Michael Cheney found a small colony of an unknown Apiaceae growing in and around a series of seepage pools in an old-growth forest margin at approximately $300 \mathrm{~m}$ elevation on south-central Graham Island in the Queen Charlotte Islands. A specimen (Cheney s.n.; V190944) was sent to the Royal British Columbia Museum (V) for identification, as it did not match any Apiaceae from British Columbia. Here it was identified as Oxypolis occidentalis J. Coulter \& Rose, using the Flora of California (Constance 1993). A specimen sent to the Rocky Mountain Herbarium (RM) (NIS\# 2003-133 [DAO]) was also identified as O. occidentalis by Ronald Hartman (RM). Specimens were also deposited in the Ministry of Forests herbarium at Smithers (S). Verification of the identification of $O$. occidentalis was based upon the original description (Coulter and Rose 1900) as well as comparison with herbarium specimens (OSU141785, OSU177111, UC177437) from Oregon and California. The Queen Charlotte Islands specimen matches these specimens in the following characters: seed morphology, little variation in ray length, and the size, shape and serration of the leaflets.

Oxypolis occidentalis is new to Canada and belongs to a solely North American genus of six species, found in eastern and western North America and the Caribbean (Constance 1993). In Canada, one other species in this genus has been collected, O. rigidior (L.) C. \& R., a species of bogs and wet meadows. This species was collected in southern Ontario in bogs, wet woods and swamps, only from 1886 to 1901 , and possibly is now extinct (Scoggan 1979).

The closest populations of $O$. occidentalis to the Queen Charlotte Islands populations are approximately $1400 \mathrm{~km}$ distant. The northernmost is from eastern Lane County (Oregon Vascular Plant Database Record: ORE103195) in westcentral Oregon as well as Jackson and Lake counties of southern Oregon (Peck 1961). The distribution of collections in California is centred in transmontane California, particularly the high Sierra
Nevada and the foothills regions of Fresno, Mariposa, Tulare, and Tuolumne counties from $1200-2600 \mathrm{~m}$ in bogs, wet meadows, streamsides and coniferous forests (Constance 1993).

In the summers of 2002 and 2003, 10 other widelydispersed sites were discovered, revealing that $O$. occidentalis ranges extensively on the south-eastern flank of the Skidegate Plateau in suitable sites from 250-370 m elevation. It is quite possible that it is also found throughout the Skidegate Plateau and in other suitable habitats in the Queen Charlotte archipelago. Only one lowland site has been discovered, at approximately $10 \mathrm{~m}$ elevation, $3 \mathrm{~km}$ north of Port Clements. Specimens of $O$. occidentalis at this site are confined to a shady area approximately $100 \mathrm{~m}^{2}$, though this small area is densely populated with $O$. occidentalis.

At the higher elevation sites on the Queen Charlotte Islands, O. occidentalis is very frequently associated with Veratrum viride, Senecio triangularis and Carex stylosa. The lowland population is associated with Angelica genuflexa, Carex cusickii, Lysichiton americanus, Menyanthes trifoliata, and Oenanthe sarmentosa. The known distribution of the populations on the Queen Charlotte Islands, along with its narrow habitat preferences and its presence in forests that have not been logged or otherwise disturbed by humans, suggest that it is not a recent introduction. Whether $O$. occidentalis is also found in some of the many suitable habitats on Moresby Island remains, for the moment, an intriguing question and one that may shed some light on its status as a native species of the Queen Charlotte Islands.

The existence of a disjunct Queen Charlotte Island population of $O$. occidentalis raises biogeographical questions. Queen Charlotte Islands specimens of $O$. occidentalis are being examined using molecular techniques at the University of Illinois as part of a systematic and phylogenetic treatment of the genus. The results of this investigation should contribute further to an understanding of the biogeographical relationships between the Queen Charlotte Islands populations and those further south. 


\section{Literature Cited}

Constance, L. 1993. Apiaceae. Page 159 in The Jepson Manual: Higher Plants of California. Edited by J. C. Hickman. University of California Press, Berkeley.

Coulter, J. M., and J. N. Rose. 1900. North American Umbelliferae. Contributions from the United States National Herbarium 7:192-196.
Peck, M. E. 1961. A manual of the Higher Plants of Oregon, second edition. Metropolitan Printing Company, Portland. Scoggan, H. J. 1978-1979. The Flora of Canada. Volumes 1-4. National Museums of Canada, Ottawa.

Received 17 September 2005

Accepted 28 June 2008 